\title{
Illness trajectory in heart failure: narratives of family caregivers
}

\author{
Trajetória da doença na insuficiência cardíaca: narrativas de cuidadores familiares \\ La trayectoria de la enfermedad en la insuficiencia cardíaca: los relatos de cuidadores familiares
}

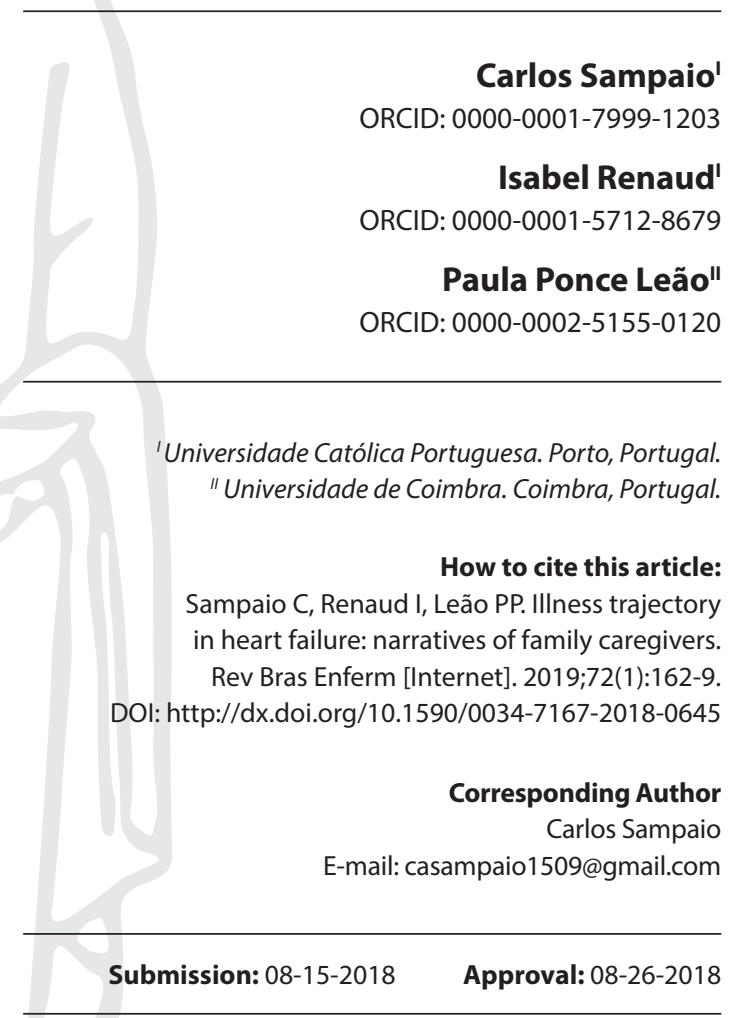

\begin{abstract}
Objective: To explore the meaning of being a family caregiver for a relative with advanced heart failure (HF) in their own home, and to gain an understanding of how dignity is upheld in family caregiving contexts. Method: We used a phenomenologicalhermeneutical method inspired by the Ricoeurian philosophy. Portuguese caregivers for relatives with advanced HF participated in two reflective interviews over a fourmonth period. Results: The ten family caregivers enrolled in this study included two daughters and eight spouses with a mean age of 70 years. We identified two main themes: (1) Struggle between inner force and sense of duty; (2) Struggle between feelings of burden and security. Final considerations: People with HF have debilitating symptoms associated with psychological stress, which can burden both them and their family caregivers. Findings support that family caregivers require participation in the planning and execution of their relative's health care.

Descriptors: Heart Failure; Family Caregivers; Personal Narratives; Qualitative Research; Caring.
\end{abstract}

\section{RESUMO}

Objetivo: Explorar o significado de ser um cuidador familiar de um parente com insuficiência cardíaca avançada (IC) em sua própria casa e compreender como a dignidade é mantida em contextos do cuidado familiar. Método: Utilizado um método fenomenológicohermenêutico inspirado na filosofia ricoeuriana. Cuidadores portugueses de familiares com IC avançada participaram de duas entrevistas reflexivas em um período de quatro meses. Resultados: Os dez cuidadores familiares incluídos neste estudo incluíram duas filhas e oito cônjuges com idade média de 70 anos. Foram identificados dois temas principais: (1) Luta entre força interior e senso de dever; (2) Luta entre sentimentos de fardo e segurança. Consideraçōes finais: Pessoas com IC têm sintomas debilitantes associados ao estresse psicológico, o que pode sobrecarregar tanto eles como seus cuidadores familiares. Os resultados apontam que os cuidadores familiares precisam participar no planejamento e na execução dos cuidados de saúde de seus parentes.

Descritores: Insuficiência Cardíaca; Cuidadores Familiares; Narrativas Pessoais; Pesquisa Qualitativa; Cuidado.

\section{RESUMEN}

Objetivo: explorar los significados de ser un cuidador familiar de un familiar con insuficiencia cardíaca avanzada en su propio hogar y comprender cómo se respeta la dignidad en el contexto del cuidado familiar. Método: se utilizó un método fenomenológicohermenéutico inspirado en la filosofía de Ricoeur. Los cuidadores portugueses de familiares con insuficiencia cardíaca avanzada participaron en dos entrevistas reflexivas durante un período de 4 meses. Resultados: los diez cuidadores familiares inscritos en ese estudio, incluyendo dos hijas y ocho cónyuges con una edad media de 70 años. Se identificaron dos temas principales: (1) La lucha entre la fuerza interior y el sentido del deber; (2) La lucha entre los sentimientos de carga y seguridad. Consideraciones finales: las personas con insuficiencia cardíaca tienen síntomas debilitantes asociados con el estrés psicológico, que pueden ser una carga para ellos y para sus cuidadores familiares. Los hallazgos confirman que los cuidadores familiares requieren la participación en la planificación y ejecución de la atención médica de sus familiares.

Descriptores: Insuficiencia Cardiaca; Cuidadores Familiares; Relatos Personales; Investigación Cualitativa; Cuidado. 


\section{INTRODUCTION}

Approximately 26 million people live with heart failure (HF) worldwide $^{(1)}$. Braunwald ${ }^{(2)}$ estimates a prevalence as high as 38 million people. In developed countries, the prevalence of HF among the adult population is approximately $1 \%-2 \%$, reaching $\geq 10 \%$ among people 70 years of age or older, a value estimated to increase to between $50 \%$ and $75 \%$ by the year $2030^{(3)}$.

The overall estimated prevalence of HF in Portugal was 4.4\%, with prevalence varying between $1.36 \%$ among the ages of 25 to 50 and $16 \%$ above the age of $80^{(4)}$. Multimorbidity in $\mathrm{HF}$ is a growing concern in older people who may experience multiple symptoms of several conditions coupled with increasing vulnerability and frailty ${ }^{(5)}$. HF is a common cause of hospitalization in people $\geq 65$ years old ${ }^{(6)}$.

Experiencing a chronic illness has devastating psychological, physical, and social consequences on individuals and their families. Previous studies showed that people with chronic illness experience loss of self because they are living a limited and uncertain life ${ }^{(7)}$.

The majority of older people with HF depend upon others for essential household tasks, such as meal preparation, shopping, and managing money ${ }^{(8-9)}$. The transition to dependency is often combined with a fear of being a burden to others. Having a cardiovascular disease such as HF requires those involved to adjust to the new situation and find solutions to the many and diverse challenges of the relative's new living conditions ${ }^{(10)}$. Family caregiving includes the provision of physical, cognitive, and emotional support and care during the often unpredictable trajectory of $\mathrm{HF}$, with its periods of constancy interrupted by exacerbations and erratic acute hospitalizations ${ }^{(11-12)}$. The family caregivers most often described in the literature are spouses, but they may also be children, siblings, or friends of the patient ${ }^{(13)}$.

Family caregivers identify deterioration in the health status of their relative and assess the severity of the illness and whether there is a need for emergency help ${ }^{(10,14)}$. Caregivers have an important role in strengthening their relative's adherence to complicated medical treatment, encouraging self-care behaviors, and in maintaining a healthy lifestyle $\mathrm{e}^{(14)}$.

Nevertheless, there is a need to recognize the challenges HF poses to the family caregiver's health and well-being, the family functioning, and the relationships within the family ${ }^{(15)}$. There is a vast amount of literature concerning the situation and role of a caregiver for a relative with $\mathrm{HF}$, with most focusing on the strenuous and negative aspects of caregiving ${ }^{(12)}$. Furthermore, persons with HF expect dignified care, but the threat of illness challenges dignity as it results in caring needs and the risk of not being seen as individual persons. In order to protect a sense of dignity, individuals need to be valued and appreciated for who they are. To this end, informal caregivers must encourage the individual's identity and show interest in understanding the person's unique individuality, value, and perception in particular contexts ${ }^{(16)}$. The final goal of caregiving is to bring the human being back to his or her mission in life, which can be described as an ethical requirement ${ }^{(17-18)}$. Family caregivers preserve their relative's dignity when they have the courage to be present, allow themselves to be touched by the care recipient's stories, and recognize their unspoken needs and wishes. This perspective fosters a sense of dignity that grows from a caring and affirmative relationship, which makes the caregivers able to view themselves from a new perspective ${ }^{(19)}$. Family caregiving can undoubtedly be rewarding and satisfying as it represents an opportunity for increased intimacy and connection with the sick person.

Given the impact of family caregiving in HF, having a good life in this problematical situation is influenced by how the needs of caregivers and relatives are satisfied. Few studies have investigated the lived experience from the perspective of family caregivers of HF sufferers, and none were conducted in Portugal.

\section{OBJECTIVE}

The current study is part of a larger project that aims to capture the meaning of living with advanced HF from the viewpoint of patients, nurses, and family caregivers. Thus, this study aims to explore the meaning of being a family caregiver for a relative with advanced $\mathrm{HF}$ in their own home and to gain an understanding of how dignity is upheld in family caregiving contexts.

\section{METHOD}

\section{Ethical concerns}

The committee for medical research ethics approved this study (P29-05/2015). The information about the study's purpose, confidentiality, anonymity, and publication was provided both orally and in writing. All participants signed an informed consent form and were informed they could withdraw from the study at any time, without any reason, and with no consequences.

\section{Type of study and theoretical-methodological framework}

This study employs a phenomenological hermeneutical method inspired by Paul Ricoeur ${ }^{(20)}$. The method has been intended "to help achieve an insight into the meaning of the interviewee's lived experiences"(21). Sharing one's own narrative and listening to that of others fosters a better understanding of how oneself and others perceive reality. Being able to narrate one's lived experiences is a manner of finding sense in one's life, understanding oneself, and shaping one's identity ${ }^{(22)}$.

According to the philosophy of hermeneutics, we always interpret the world in the light of our preunderstanding. With a hermeneutic approach, knowledge building may be seen as a circle where new knowledge fuses with previous knowledge ${ }^{(23)}$. Preunderstandings influence both the interview guidelines and the interviews conducted by the researchers. Our preunderstandings in this study are based on different experiences of caring for older people, clinical nursing and research, as well as earlier theories and research about dignity.

\section{Data source}

Ten caregivers for relatives with advanced HF, as classified by the New York Heart Association functional class III or IV ${ }^{(24)}$, were purposively at one urban hospital in the central region of Portugal. 
All family caregivers accessible when data was collected were asked to participate and given written information about the study. The inclusion criteria were: $a$ ) at least six months experience as caregivers; b) ability to speak and understand the Portuguese language; and c) willingness to participate in the study.

\section{Collection and organization of data}

Each caregiver participated in two reflective and face-to-face interviews over a four-month period (between June 2015 and May 2016). All interviews were conducted by the first author and carried out at the participant's home.

In total there were twenty interviews. The interview schedule was constructed by the research team based on the literature on HF and family caregiving ${ }^{(9,11)}$. We used open-ended questions to encourage narrative replies ${ }^{(21)}$. We used an inductive approach and asked the family caregivers to freely describe and reflect upon different caregiving situations: their experiences as caregivers and how it affected their relationship with their relative with $\mathrm{HF}$ and life in general; their needs and how these could best be met; and lastly how the concept of dignity can affect one's day-to-day practice.

The participants responded with insights regarding the themes based on their own life experiences and reflections. We also conducted probes and asked follow-up questions, such as: 'So what I hear you saying is...' or 'Could you please tell me more about...' The interviews lasted 45-60 minutes and were tape-recorded and transcribed verbatim, including nonverbal communication indications of crying, silences, emphasis, etc.

\section{Data analysis}

We imported the transcribed material into the QSR NVivo10 software program for management purposes ${ }^{(25)}$. The first author transcribed the interviews verbatim and, when reading and rereading each interview as a whole, noted the themes that arose. Additionally, the second and third authors supervised the entire research process, validating the results by reading the transcribed interviews and accompanying the interpretation process. We discussed results and interpretation until we reached a consensus.

We performed the data analysis using a qualitative method appropriate to the "phenomenological-hermeneutic approach of Paul Ricoeur's interpretation theory"(26). First, a naïve understanding of the text is presented, the text is divided into

Chart 1 - Demographics of participants $(n=10)$ meaning units, and those meaning units are then condensed into both subthemes and themes. After this process of analysis, the entire text is read through to validate the naïve understanding and meaning units, and, if necessary, these are adjusted. Lastly, a comprehensive understanding is formulated. The process of interpreting the text can be described as a hermeneutic circle or hermeneutic spiral. By alternating between the parts of the text and the whole, a new understanding arises, and the essential meanings need to be revealed and interpreted throughout the text ${ }^{(26)}$.

The concerns with decisions made by the researchers were recorded and explained during all stages of the analysis ${ }^{(27)}$. As a research team, the project members read the data material as a text, discussed it, and gave suggestions for preliminary interpretations. Researcher preconceptions and assumptions were controlled, to some degree, by bracketing and continuous discussions within the research group. Thus, researcher triangulation increased the validity of interpretations.

To increase conformability, we tried to describe the analysis process as clearly as possible and use quotations to ground findings upon the data. The same interview guide was used for all interviews, enhancing dependability, and a single researcher performed all interviews. In addition, theme descriptions were presented to some participants for member checking.

\section{RESULTS}

The participants consisted of eight spouses and two daughters. The spouses were cohabiting with the person with HF, whereas the daughters were not. Caregivers were between 50 and 85 years old (mean $=70$ years old) and had 6 months to 2 years caregiving experience at the time of data collection (see Chart 1). This sample was relatively homogenous with respect to socioeconomic status (they could all be considered middle class) and ethnic background (all were of European descent).

\begin{tabular}{|c|c|c|c|c|c|c|}
\hline Participant & Gender & Age & Education & $\begin{array}{c}\text { Relationship } \\
\text { to the cared } \\
\text { for person }\end{array}$ & $\begin{array}{c}\text { Length of time } \\
\text { as a caregiver }\end{array}$ & $\begin{array}{c}\text { Employment } \\
\text { status }\end{array}$ \\
\hline P1 & Female & 71 & Illiterate & Spouse/partner & 24 months & Retired \\
\hline P2 & Female & 74 & Elementary & Spouse/partner & 15 months & Retired \\
\hline P3 & Female & 62 & $\begin{array}{c}\text { Bachelor's } \\
\text { degree }\end{array}$ & Daughter/mother & 6 months & $\begin{array}{c}\text { Working-age, } \\
\text { full-time caregiver }\end{array}$ \\
\hline P4 & Female & 71 & Elementary & Spouse/partner & 18 months & Retired \\
\hline P5 & Female & 50 & $\begin{array}{c}\text { Master's } \\
\text { degree }\end{array}$ & Daughter/mother & 8 months & Employed \\
\hline P6 & Female & 70 & Elementary & Spouse/partner & 15 months & Retired \\
\hline P7 & Female & 85 & Elementary & Spouse/partner & 10 months & Retired \\
\hline P8 & Female & 72 & Elementary & Spouse/partner & 12 months & Retired \\
\hline P9 & Female & 74 & Illiterate & Spouse/partner & 13 months & Retired \\
\hline P10 & Female & 68 & Elementary & Spouse/partner & 24 months & Retired \\
\hline
\end{tabular}




\section{Naïve reading}

We read and re-read all the interview transcriptions many times to add an idea of overall content ${ }^{(26)}$. Afterward, we formulated the following assumptions about the meaning of the text: to provide care for a close relative with advanced HF implies: living a burdensome everyday life, living with the fear of lacking the strength to assist the relative as much as one desires, or that the family member may abruptly die. To be a family caregiver means a mixture of feelings of uncertainty and vulnerability. It means experiencing security in spite of the illness and focusing on other resources that make life easier. Support by healthcare staff seems to alleviate the burden, mainly by assisting the person with advanced HF and encouraging a normal life at home.

\section{Structural analysis}

The two themes, each with two subthemes, revealed by the data are summarized in Chart 2. Themes and subthemes are described in detail and supported with quotes.

Chart 2 - Themes and subthemes from the structural analysis

\begin{tabular}{|l|l|}
\hline \multicolumn{1}{|c|}{ Themes } & \multicolumn{1}{c|}{ Subthemes } \\
\hline $\begin{array}{l}\text { Struggle between } \\
\text { inner force and } \\
\text { sense of duty }\end{array}$ & The ethical basis for caregiving: utility or duty \\
\cline { 2 - 2 } $\begin{array}{l}\text { Struggle between } \\
\text { feelings of burden } \\
\text { and security }\end{array}$ & Providing better care while protecting oneself \\
\cline { 2 - 2 } & Preserving dignity \\
\hline
\end{tabular}

\section{Theme 1: Struggle between inner force and sense of duty}

This theme was formulated based on the family caregivers' perceptions and experiences about caregiving as a human duty. Caregiving is viewed as a part of natural aging in the context of chronic illness. However, for some, it was an unexpected or even intrusive element in their lives. As such, they struggled with setting boundaries on the caregiver's role to preserve their own selfidentity. We constructed the theme from the following subthemes.

The ethical basis for caregiving: utility or duty. Some participants accepted the role of caregiver because of feelings of love, reciprocity and, in one case, possibly some utilitarianism.

We take care of each other. It doesn't always happen, but it's supposed to. I think it's what people want to do. (P3)

P6 thought what people feel about this human obligation might be changing:

I was brought up in an age when you took care of the person, not like it is now. (P6)

And P1 elaborated on abdicating the family caregiver's duty:

A lot of people, they'll take their family member to a nursing home and never come back and see them. (P1)
They spoke about their relative's uniqueness and deserving of care as an expression of love. P7 was short but emphatic:

It's just the way I feel. She's my whole life. (P7)

For P9, in addition to being committed to his partner, there may have been a utilitarian aspect to his caregiving:

I'm getting social security, and I probably wouldn't get a full check if we were married. If something happens to him, I don't know what I'll do, because my only income is the social security check. (P9)

Caregiving was seen as a natural evolution of aging. There was a sense of teamwork in the role as both partners were developing various health issues as a part of aging:

We help each other with the meds, we get our monthly or twoweekly box out, and she does hers, and I do mine. (P1)

Providing better care while protecting oneself. This subtheme describes how family caregivers examine their performance in the caregiving role. Family caregivers tried to maintain a sense of inner force while answering the call for caregiving, and they questioned themselves when they felt they'd acted poorly in a caregiving situation. They derived pride from learning skills needed to become better caregivers, and they worried about their own health and how it might be limiting their capacity to act.

P7 prided herself on her appearance and continued sharp intellect at age 85:

Idon't know what 85 looks like, or how a 85-year-old is supposed to act. I don't feel like I can be that old, you know? As long as I'm able to do whatever I like to do... (P7)

P10 felt her baking was in continued demand:

My grandson did call me the other day, he said 'Grandma, I'm going deer hunting, can you make this for me? And this? And this? To take? Because it's a bunch of guys, they always take stuff! (P10)

P1 was trying to describe how her improved symptom interpretation increased her esteem for herself and others:

I guess I would call it trust, or maybe faith and trust together. Trust in my judgment and, well, in all the doctors. I think faith in the fact that I did the right thing at the right time. I can handle it better. When it first happened, it scared me. (P1)

P10 was proud of being able to adapt her cooking:

You learn more [...] I knew the hypertension way to cook. And yet I try to fix some of the things he likes. (P10)

Some caregivers described the awareness of resources, such as optimism and humor. P8 added:

I really have a good sense of humor and I'm prepared to care for my spouse. (P8) 
Participants felt lower self-esteem when they believed they failed in their caregiving. P4 had arthritis and was newly diagnosed with diabetes, but she hoped it would not affect her caregiving:

$$
\text { So that should behave itself! I hope! (P4) }
$$

She said the only negative health effect of caregiving was that she "was tired a lot." P7 felt guilty for moments of anger:

I get angry at him, yes. Then I just leave the room and do something else. Pretty soon, it's gone. But I do get angry at myself for being angry. I do. 'Why did you do that?' I question myself. (P7)

\section{Theme 2: Struggle between feelings of burden and security}

The participants spoke of new responsibilities in their everyday life that challenged established roles in the relationship and were described as arduous but were also perceived as a means for personal development. The theme'Struggle between feelings of burden and security' was formed from the subthemes Feeling captive in illness and Preserving dignity.

Feeling captive in illness. The family caregivers were responsible for medication regimens, all homecare, and for comforting and encouraging their relative. They lived an ever-present uncertainty caused by the unpredictable course of HF. In the event of sudden deterioration, the participants wanted to be physically present, which restricted their possibilities to travel and engage in personal activities outside of the home. Particularly difficult for the participants was witnessing their relative's gradual decline and the lack of good days.

All family caregivers felt that the stress of caregiving affected their own health, and therefore impaired their capacity to act. P10 admitted experiencing depression and loss of confidence and hope:

I think that, as a caregiver, sometimes the downs become too many. (P10)

P1 reported stress-related weight gain:

I just feel that sometimes mental and emotional turmoil takes a greater toll on us than anything we can do physically. I've probably gained 20 pounds since I met him. (P1)

She felt anxious a lot of times, especially when her relative had uncontrollable breathlessness or lacked the energy to pick up after himself:

I get anxious when bad things happen to the house. (P1)

The family caregivers experienced increased vulnerability when confronted with situations in which they caused the relative's suffering. The narratives revealed that the participants want to be efficient and of use to themselves and others, but that their lack of strength led to feelings of being useless.

I want to be useful, you know, but I'm feeling tired. (P2)

I'm afraid that fatigue will overcome my capability to do what is expected. (P6)
Preserving dignity. From the viewpoint of some caregivers, a sense of responsibility in carrying out their duties enhances the dignity of their relatives with HF.

It's a great responsibility, very much so. I feel hesitant when I leave my spouse at home alone because a crisis could happen. (P3)

Family involvement in the health team and communication with respect are two important subjects for patient dignity. Participants confirmed that mutual respect in communication is one of their most significant wishes.

My husband and I don't want anything apart from dignity and respect. (P8)

Home healthcare providers boosted self-esteem when they provided humor and a personal connection. P10 enjoyed the home healthcare team that came to the house for a few weeks:

She was a nurse. He and she just hit it off. She was always calling him dad. He'd say, 'you look tired, be careful driving home,' so she'd say, 'yes dad.' That helped, they were so good to him. (P10)

Being treated as people and having their emotions acknowledged by healthcare staff was supportive:

[Doctor] called me. Every day, or so, he calls me to check how I am, and he feels so bad. (P2)

P1 felt rewarded when she brought the care recipient in during an emergency:

They told me that because of the way she responded this time, she's going to come out of it quicker and easier. The nurse said: 'You caught it in time and the most important thing is timing for something like this. (P1)

Positive feedback from visiting nurses was empowering for P7, P9, and P10.

After he came home from the hospital, the visiting nurse stopped by to see him. That was good. Everything was well. She does that to be sure he's doing okay and getting the proper care. (P10)

Healthcare staff relieved the family caregiver's emotional burden by offering support, presence, and competence in caring for the patient in times of crisis. That is what P7 needed and received from the nurses:

[They] are so kind. 'We're going to do everything we can to get him better; you just leave him in our care. We're going to make sure he gets well,' so it takes some of that burden off of you. (P7)

P9 found friendship support in the most unlikely place at the hospital: once, when she was feeling particularly discouraged, the valet at the hospital

Comes up to me and puts his arm around me and says 'I'm praying for him.' When you get people in the hospital encouraging you, then you have a large network of people to care. (P9) 


\section{DISCUSSION}

In the last stage of the study, we analyzed the narratives as a whole, considering the findings from the naïve reading, the structural analysis, and authors' preunderstanding ${ }^{(26)}$.

Demographics of this group of participants matched the general family caregiver population as described in the literature: mostly female and older people ${ }^{(11)}$.

Findings from this study provide philosophical underpinnings of duty, amity, capacity to act, and ethical motivation for much of what is known in the literature about HF caregiving so far. This study adds to current theory guiding HF care by giving voice to caregivers, who are instrumental in supporting their relatives in outpatient management of HF. The caregiving trajectory in HF parallels the course of the disease, a trajectory of gradual decline punctuated by acute, life-threatening exacerbations that can be treated aggressively, returning to a state of improved, equal, or slightly diminished function, and ending with a gradual decline. In accompanying the person with HF along their illness trajectory, family caregivers repeatedly confirm their suspicions of a change in health, challenge the change, and try to establish new normality, until they acknowledge that the end of life is near ${ }^{(12)}$.

Studies reveal "how caring for chronically ill family members at home influences various aspects of a caregiver's life". "These effects are physical, psychological and social and may include worsened physical health, impaired social and family life, and increased stress, anxiety and depression"(28). The participants spoke of self-sacrifice and feelings of hopelessness and exhaustion, but also found ways to restore strength, to strengthen their motivation to care and to move forward with their lives. The participants were thankful for still having their family member by their side and perceived caregiving as a means of achieving increased intimacy and cohesion with one another. For the family caregivers, it was important that their relative did not take caregiving for granted, but instead valued and understood that HF also influenced the caregiver's life.

Reflecting on their own strengths and weaknesses, family caregivers described various sources of esteem as well as situations where they felt unsure intellectually, emotionally, and physically. They constantly assessed whether either themselves or the people with HF were lacking dignity or respect, and engaged in negotiations about fairness, courtesy, and the tension between protecting mutual sensibilities in daily activities and caregiving tasks. Such tension in the context of living with chronic illness was described by Delmar et al. ${ }^{(29)}$, from the perspective of people with HF, in terms of independence, self-responsibility, and selfcontrol in caregiver-care recipient relationships.

Caregivers would like to discriminate among therapeutic choices and approve decisions they believe to be in the patient's best interest ${ }^{(9)}$. That instigates a sense of pleasure and maintains the relative's dignity. Caregivers needed to preserve dignity and respect not only for the person with HF, but also for themselves, in intimate daily acts of physical care, treatment adherence, and symptom management, and also in seeking time and space of their own. On one study, family caregivers had only an unclear understanding of HF pathophysiology but were well informed about the effects of symptoms on their relatives ${ }^{(10)}$. They wanted to offer appropriate support and encouragement and needed to assess the care recipients' capacity daily ${ }^{(10)}$. Generally, these negotiations occurred within established interaction patterns and were complicated by the introduction of vulnerability, dependence, and burden into the relationship. Suffering is likely to decrease if the caregivers, and the family as a whole, live mainly within the current moment, even with the experience of severe illness, and accept "what is now" rather than emphasizing on the past or future and continuously challenging the present ${ }^{(30)}$.

The interactions with healthcare providers increased the family caregiver's perceived control in the caregiving situation. Family caregivers needed to have their experience and capacity to act validated and affirmed. They appreciated the health care professionals' forthrightness about the prognosis of their relative's HF, which could result in their relative's acceptance of more realistic expectations and plans. Social support was recognized as a protective factor during times of medical instability when more practical help and friendship support was desired by family caregivers ${ }^{(31)}$.

\section{Study limitations}

Consistent with the nature of the phenomenological inquiry, the sample size was small and homogeneous, consisting of mostly older white partners of spouses with HF. Participants were recruited from one hospital only and reflect the experience within a limited region of Portugal (central region). Information on the medical severity of the heart failure was not collected, and we did not uncover whether the family member's experiences changed with the disease's severity. It is feasible that additional research approaches would reveal more knowledge about the care experiences in this population. In addition, this study was performed in Portugal, and the needs of family caregivers may diverge for individuals from other cultures.

\section{Contributions to the field of nursing, health, or public policy}

Participants described how symptoms' progress caused anxiety and left them unable to plan for the future. Living one day at a time was not a coping strategy, but a way of life forced upon them by being kept in the dark about the future. The caregiver's emotional turmoil and sense of burden should be assessed as an element of routine and ongoing care, and action should be taken to support them in their role ${ }^{(32)}$. Supported by previous research ${ }^{(9)}$, this study also argues that many caregivers are ready and able to use self-management resources but must be prepared with the required information and abilities, provided through proper communication with healthcare providers. Nursing practice in home care should guarantee that caregivers are prepared to sustain the management of HF and able to satisfy their own needs as they "adjust to becoming caregivers"(9). That may be a challenge, as caregivers may conceal their feelings and responses because they experience an obligation to care. Caregivers entail individual, social, and formal strategies "to meet their needs and to care for a person with $\mathrm{HF}^{\prime \prime(10)}$.

"Caregivers should be actively included in the treatment and the care planning decisions, as this can improve HF self-care, but also improve communication with the health care professional"(9). 
Several practical implications arise based on the viewpoint of family caregivers. As part of an ongoing process, staff needs to: discuss which overarching values are important for taking care of patient dignity; emphasize cooperation with family caregivers as an integral component of patient care protocols; and reduce the asymmetry in the relationship between patients and staff(33). That will help develop dignified nursing practice.

A political agenda is also required to: stimulate monetary benefits, "career advancement","geriatric education and training", and "long-term care policies to increase the geriatric care workforce"; and to strengthen Social Security by "valuing the labor of family caregivers who leave the workforce to provide full-time support and care for an ill family member"(34).

We consider this qualitative study has significant implications for other chronic conditions for which more research is needed.

\section{FINAL CONSIDERATIONS}

This study is the first phenomenological exploration of the lived experience of being a caregiver to a relative with HF in Portugal. An explicit gain of employing a phenomenological approach to inquiry is we captured the experience from the first-person perspective. As a result, nurses and other health professionals are better able to assist family caregivers and apply interventions that are most significant to these individuals.

Understanding the experience of caregivers, their thoughts, feelings, and difficulties can lead to the development of coping strategies that alleviate their stress. Towards this purpose, one must recognize the importance of communication about shared illness experience, decision-making on how to react to the illness, and interpersonal relationship abilities in care actions.

\section{REFERENCES}

1. Ambrosy, A, Fonarow, G, Butler J, et al. The global health and economic burden of hospitalizations for heart failure: lessons learned from hospitalized heart failure registries. J Am Coll Cardiol [Internet]. 2014 [cited 2018 May 4]; 63(12):1123-33. Available from: http:// dx.doi.10.1016/j.jacc.2013.11.053

2. Braunwald E. The war against heart failure: The Lancet lecture. Lancet [Internet]. 2015[cited 2018 May 4]; 385(9970):812-24. Available from: http://dx.doi.10.1016/S0140-6736(14)61889-4

3. Mosterd A, Hoes A. Clinical epidemiology of heart failure. Heart [Internet]. 2007 [cited 2018 May 4]; 93:1137-46. Available from: http:// dx.10.1136/hrt.2003.025270

4. Ceia F, Fonseca C, Mota T, et al. Prevalence of chronic heart failure in Southwestern Europe: the EPICA study. Eur J Heart Fail [Internet]. 2002 [cited 2018 May 25];4:531-39. Available from: http://dx.doi.org/10.1016/S1388-9842(02)00034-X

5. Benjamin E, Blaha M, Chiuve S, et al. American Heart Association Statistics Committee and Stroke Statistics Subcommittee. Heart disease and stroke statistics - 2017 update: a report from the American Heart Association. Circulation [Internet]. 2017 [cited 2018 May 4];135(10):e146-e603. Available from: http://dx.doi:10.1161/CIR.0000000000000485

6. Roger V. Epidemiology of heart failure. Circ Res [Internet]. 2013 [cited 2018 May 4]; 113(6):646-59. Available from: http://dx.doi:10.1161/ CIRCRESAHA.113.300268.

7. Chiaranai C, Chularee S, Srithongluang S. Older people living with chronic illness. Geriatr Nurs. 2018 Mar 26. pii: S0197-4572(18)30048-X. doi: 10.1016/j.gerinurse.2018.02.004

8. Norberg E, Boman K, Löfgren B. Impact of fatigue on everyday life among older people with chronic heart failure. Aust Occup Ther J [Internet]. 2010 [cited 2018 Feb 15]; 57(1):34-41. Available from: http://dx.doi:10.1111/j.1440-1630.2009.00847.x.

9. Wingham J, Frost J, Britten N, et al. Needs of caregivers in heart failure management: A qualitative study. Chronic Illn [Internet]. 2015 [cited 2018 Feb 15];11(4):304-19. Available from: http://dx.doi.org/10.1177/1742395315574765.

10. Clark A, Spaling M, Harkness $K$, et al. Determinants of effective heart failure self-care: a systematic review of patients and caregivers perceptions. Heart [Internet]. 2014 [cited 2018 May 25];100(9):716-21. Available from: http://dx.doi.10.1136/heartjnl-2013-304852.

11. Kang X, Li Z, Nolan, M. Informal caregivers' experiences of caring for patients with chronic heart failure: systematic review and metasynthesis of qualitative studies. J Cardiovasc Nurs [Internet]. 2011 [cited 2018 Feb 15];26(5):386-94. Available from: http://dx.doi: 10.1097/JCN.0b013e3182076a69.

12. Dionne-Odom J, Hooker S, Bekelman $\mathrm{D}$, et al. Family caregiving for persons with heart failure at the intersection of heart failure and palliative care: a state-of-the-science review. Heart Fail Rev [Internet]. 2017 [cited 2018 Feb 15]; 22(5):543-57. Available from: http:// dx.doi:10.1007/s10741-017-9597-4

13. Usher B, Cammarata K. Heart Failure and Family Caregiver Burden: an update. Prog Cardiovasc Nurs. 2009;24(3):113-4. doi: 10.1111/j.1751-7117.2009.00046.x.

14. Buck H, Harkness K, Wion R, et al. Caregivers' contributions to heart failure self-care: a systematic review. Eur J Cardiovasc Nurs [Internet]. 2015 [cited 2018 May 25];14(1):79-89. Available from: http://dx.doi.10.1177/1474515113518434.

15. Lum H, Lo D, Hooker S, et al. Caregiving in heart failure: Relationship quality is associated with caregiver benefit finding and caregiver burden. Heart Lung [Internet]. 2014 [cited 2018 May 25];43(4):306-310. Available from: http://dx.doi:10.1016/j.hrtlng.2014.05.002.

16. Franklin L, Ternestedt B, Nordenfelt L. Views on dignity of elderly nursing home residents. Nurs Ethics. 2006;13(2):130-46.

17. Eriksson K. The suffering human being. Chicago: Nordic Studies Press; 2006. 108 p. 
18. Kangasniemi $M$, Vaismoradi $M$, Jasper $M$, et al. Ethical issues in patient safety: Implications for nursing management. Nurs Ethics. 2013;20(8):904-16.

19. Edlund M, Lindwall L, Post I, et al. Concept determination of human dignity. Nurs Ethics. 2013; 20(8):851-60.

20. Ekman I, Skott C. Developing clinical knowledge through a narrative-based method of interpretation. Eur J Cardiovasc Nurs. 2005;4(3):251-56.

21. Ricoeur P. Interpretation theory: discourse and surplus of meaning. Forth Worth (TX): Christian University Press; 1976.107 p.

22. Ricoeur P. Hermeneutics and the human sciences: essays on language, action and interpretation Cambridge (UK): Cambridge University Press; 1995. $309 \mathrm{p}$

23. Gadamer H. Truth and Method. London, New York: Continuum; 2004. 632 p.

24. Remme WJ, Swedberg K; Task Force for the Diagnosis and Treatment of Chronic Heart Failure, European Society of Cardiology. Guidelines for the diagnosis and treatment of chronic heart failure. Eur Heart J. 2001;22(17):1527-60. Erratum in: Eur Heart J 2001;22(23):2217-8.

25. QSR International. NVIVO [Internet] Melbourne (AU): QSR International; 2012 [updated 2018; cited 2018 Feb 2]. Available from http://www. qsrinternational.com/products_nvivo.aspx

26. Lindseth, A, Norberg, A. A phenomenological hermeneutical method for researching lived experience. Scand J Caring Sci. 2004;18(2):145-53.

27. Graneheim U, Lundman B. Qualitative content analysis in nursing research: concepts, procedures and measures to achieve trustworthiness. Nurse Educ Today. 2004;24(2):105-12.

28. Lim JW, Zebrack B. Caring for family members with chronic physical illness: a critical review of caregiver literature. Health Qual Life Outcomes. 2004;2:50.

29. Delmar C, Boje T, Dylmer D, et al. Independence/dependence - a contradictory relationship? Life with a chronic illness. Scand J Caring Sci. 2006;20(3):261-68.

30. Wright L. Eckhart Tolle's spiritual words of wisdom: Application to family nursing practice. J Fam Nurs. 2015;21(4):503-7. doi:10.1177/1074840715606244.

31. Hupcey J, Fenstermacher K, Kitko L, et al. Palliative Needs of Spousal Caregivers of Patients with Heart Failure Followed at Specialized Heart Failure Centers. J Hosp Palliat Nurs [Internet]. 2011 [cited 2018 May 25];13(3):142-50. Available from: http://dx.doi.org/10.1097/ NJH.0b013e31820ce15e.

32. Wingham J, Frost J, Britten N. Behind the smile: qualitative study of caregivers' anguish and management responses while caring for someone living with heart failure. BMJ Open [Internet]. 2017 [cited 2018 May 25];7(7):e014126. Available from: http://dx.doi: 10.1136/ bmjopen-2016-014126.

33. Cené C, Haymore L, Lin F, et al. Family member accompaniment to routine medical visits is associated with better self-care in heart failure patients. Chronic Illn [Internet]. 2014 [cited 2018 May 25]; 11(1):21-32. Available from: http://dx.doi.10.1177/1742395314532142.

34. Family Caregiver Alliance, National Center on Caregiving. National Policy Statement [Internet]. San Francisco (CA): Family Caregiver Alliance; 2018 [updated 2018; cited 201825 July]; Available from: https://www.caregiver.org/national-policy-statement 